\title{
Characterisation and evolution of the River Rhine system
}

\section{F. Preusser}

Institute of Geological Sciences, University of Bern, Baltzerstrasse 1-3, CH-3012 Bern, Switzerland. Email: preusser@geo.unibe.ch

Manuscript received: February 2005; accepted: July 2007

\begin{abstract}
The River Rhine and its tributaries represent one of the largest drainage systems in Europe. Its prominence among other fluvial systems is due to the location of its headwaters within the central Swiss Alps, which were repeatedly glaciated during the Quaternary, and the concurrence of major parts of the River Rhine course with the European Cenozoic Rift System. Sediments of the Rhine have thus recorded both changes in climate and tectonic activity as well as sea level change in the lower part of the river course.

The River Rhine is composed of different subdivisions characterised by distinct geographical and geological settings. Vorder- and Hinterrhein in the headwaters are inner-alpine rivers frequently influenced in their course by tectonic lines and the blockage of valley floors by the deposits of mass movements. The Alpenrhein is located in a main Alpine valley that drains into a large foreland basin, the Bodensee (Lake Constance). The Hochrhein flows out of the lake following the Jura Mountains in a western direction. All these areas display a series of geological features such as moraine ridges and outwash plains, which directly reflect Quaternary glaciations of the Alps. The Oberrhein (Upper Rhine) Valley, as a graben structure, is part of the rifting system that started to develop during the middle Tertiary. The northern end of the graben is represented by the triple junction of the Mainz Basin, which is mainly characterised by the remains of marine transgressions that occurred during the initial rifting phase. The Rhine continues following the western branch of the tectonic system by passing through the Rhenish Massif. Uplift in this socalled Mittelrhein (Middle Rhine) area is well documented by a flight of late Tertiary to Quaternary river terraces. This region is also characterised by young volcanic activity as found, for example, in the Eifel volcanic field. The Niederheinische Bucht (Lower Rhine Embayment), especially the Roer Valley Rift System, represents the northern continuation of the rifting system. This area is characterised by differential uplift in the southern and subsidence in the northern part of the basin, which continues into the Netherlands. Here, the main stream of the River Rhine is separated into different branches developing an active delta at the coast of the North Sea. When the North Sea Basin was covered by ice during the Elsterian, Saalian and probably also the Weichselian glaciation and global sea level was low, the Rhine continued its course through the English Channel and flowed into the North Atlantic off Brittany.
\end{abstract}

Keywords: Geomorphology, fluvial sediments, neotectonics, Quaternary, Tertiary

\section{Introduction}

The River Rhine (German: Rhein, French: Rhin, Dutch: Rijn) together with its tributaries represents one of the largest drainage systems of Europe. It drains most of the northern and central Swiss Alps, large areas of southern and western Germany, parts of eastern France and Belgium, and a large portion of the Netherlands (Fig. 1). It is unique among many other river systems due to its specific setting along one of the most active tectonic lines of Europe, the European Cenozoic Rift System
(Fig. 2), and the location of its main headwaters within the central part of the western Alps. The latter were repeatedly glaciated during the Quaternary as a result of naturally occurring climate change. Consequently, deposits of the River Rhine have recorded both tectonic developments and climateinduced changes in river dynamics. Furthermore, the River Rhine system is an important sediment source for the southern North Sea Basin and changes in fluvial dynamics will hence have an impact on deposition in the basin (Rijsdijk et al., 2005). 


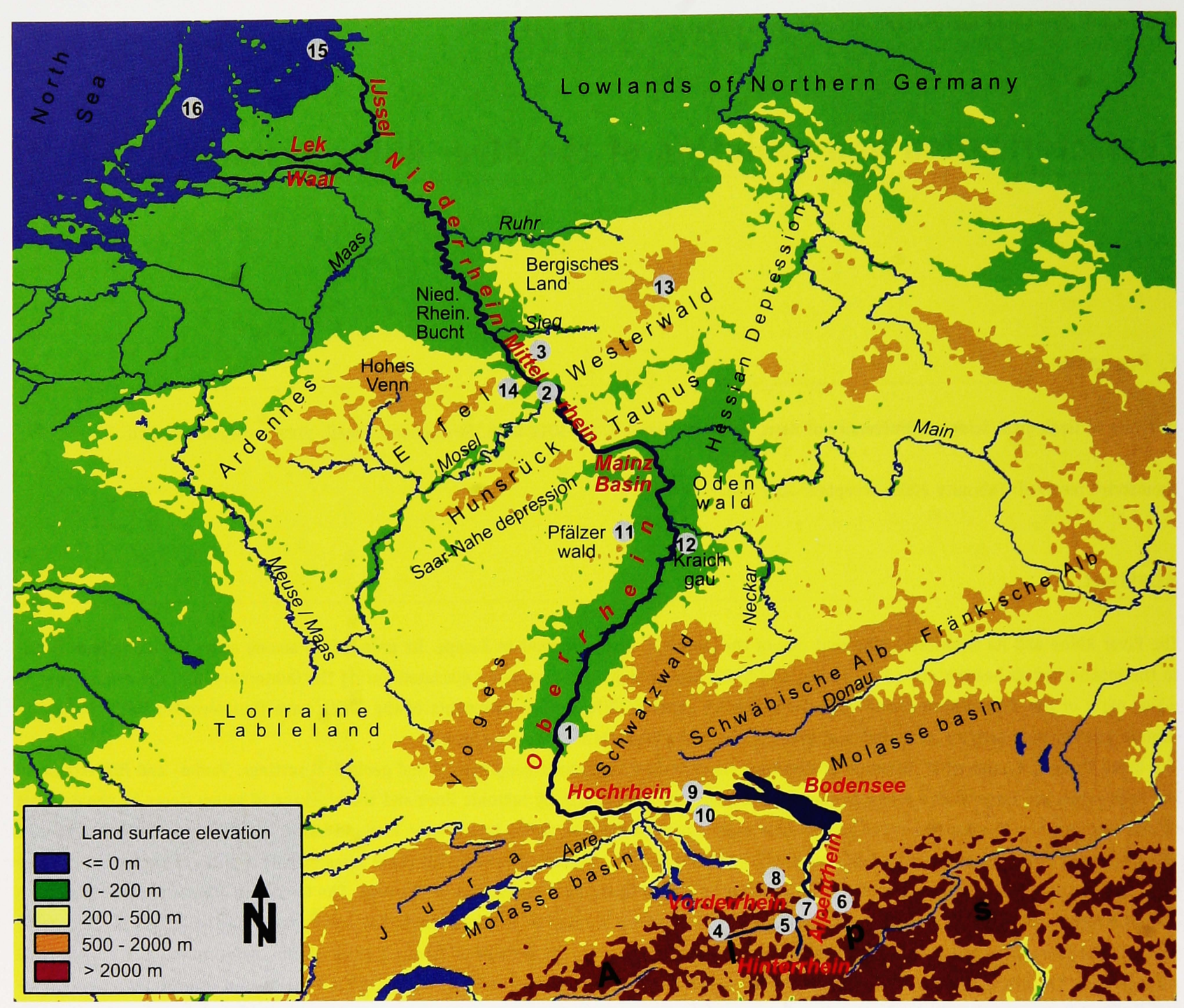

Fig. 1. Map showing the general setting along the River Rhine system including the location of relevant sites mentioned in the text (numbers follow the appearance in the text): 1 - Kaiserstuhl (volcano); 2 - Neuwied Basin; 3 -Siebengebierge; 4 - Oberalppass; 5 - Flims rockslide; 6 - Silvretta group; 7 - Tamins, Kunkel and Domat/Ems mass movements; 8 - Walensee passage; 9 Rhine Falls; 10 - Irchel; 11 - Forst site; 12: Heidelberg Basin; 13 - Rothaargebirge; 14 - Laacher See (volcano); 15 - IJsselmeer; 16 - The elevation model used in this figure refers to land surface in relation to mean sea level. Due to this, mainland below sea level, mainly caused by human activity especially in the Netherlands, appears to be 'underwater.'

The following gives an overview of the different sections of the Rhine system, all of which show a distinct character due to their specific geographical and geological setting. First, a brief introduction is given to the general tectonic and geological situation. Furthermore, the late Tertiary and Quaternary evolution of the Rhine is briefly summarised. In this context, it is necessary to refer to the recently rather controversial discussion about the definition of the Quaternary and especially its lower boundary (Gibbard, 2004; Gibbard et al., 2005; Clague 2006). Although the presently 'official' age of the Pliocene/ Pleistocene boundary is set to 1.8 Ma (Aguirre \& Passini, 1985; Partridge, 1997; Remane et al., 2002), which refers to the Vricca section in Italy, referred here to is the in the present context more reasonable age for the boundary of 2.6 Ma. 'Tertiary', which is not an 'official' stratigraphic term at the moment, is used when referring to both the Palaeogene and Neogene.

\section{General tectonic and geological setting}

The Alpine orogeny results from the convergence of the European and African plates with major faulting and rising of the Alps during the Tertiary. The outer part of the western Alps is built up by mainly intensively folded late Palaeozoic and Mesozoic sediments. The interior of the Swiss Alps is characterised by crystalline rocks, such as the intrusions of the Aare and Gotthard Massif.

The molasse basin, representing debris of Alpine erosion of Tertiary age deposited in shallow marine and fluvial environ- 


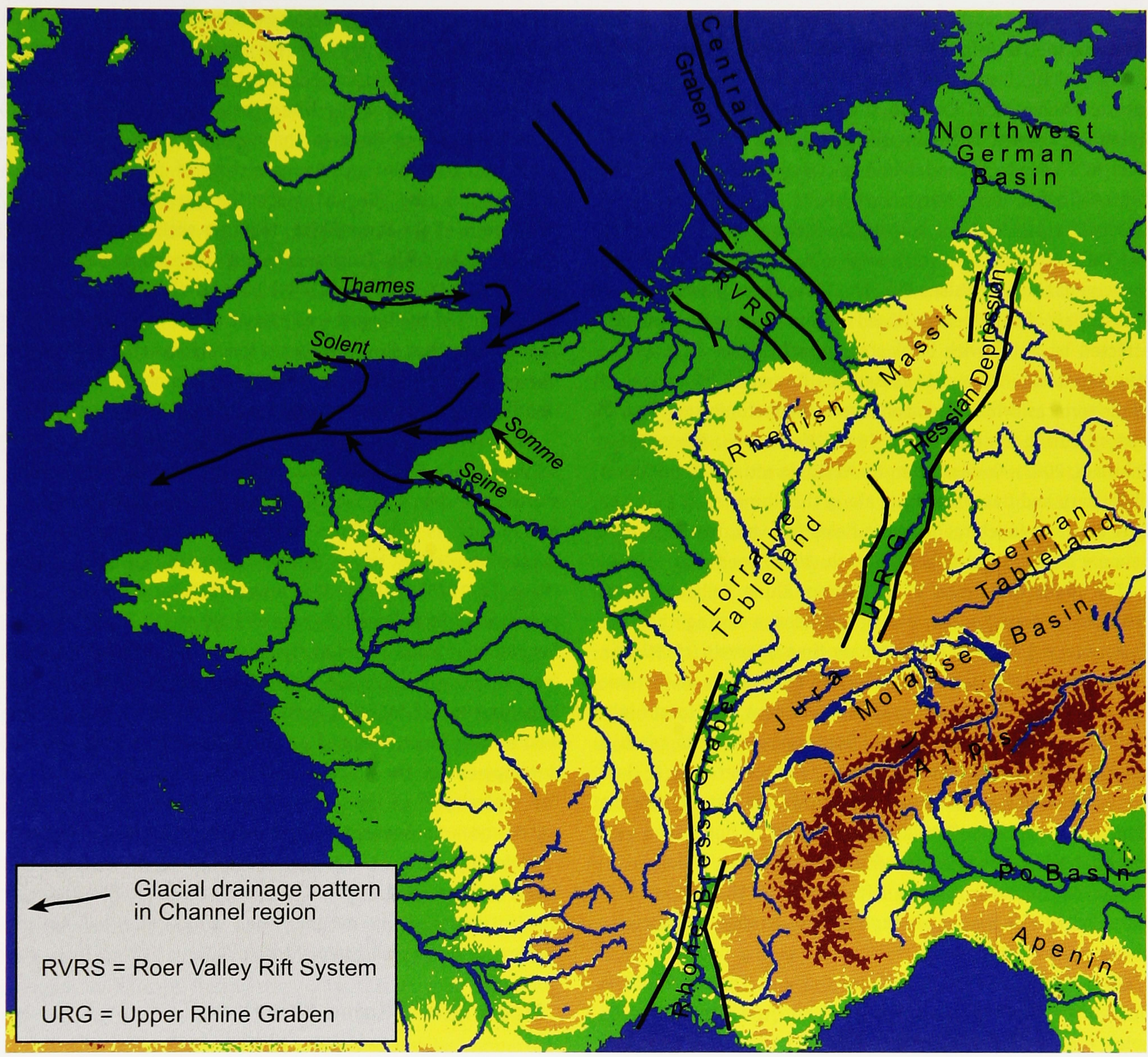

Fig. 2. Schematic map of the general tectonic setting along the Cenozoic rift system of Central Europe and assumed drainage pattern in the English Channel region during Middle and Late Pleistocene glaciations (after Gibbard, 1988; Laubscher, 2001; Michon et al., 2003; Schirmer, 2003; Sissingh, 2001, 2003). See Fig. 1 for legend and comment on elevation model.

ments, is located around the margin of the Alps (cf. Sissingh, 1997). In the western part of the Alpine Foreland, the Jura Mountains, situated north of the molasse basin, represent a range of Mesozoic sediments folded in the late part of the Alpine orogeny, probably during the Late Miocene (Laubscher, 2001). Further north follows a tectonic block built up by Permian to Cretaceous, weakly folded sediments consisting mainly of sandstone and limestone (from west to east: Lorraine Tableland, Schwäbische Alb, Fränkische Alb). Tectonic stress cohering with the faulting of the Alps initiated rifting within this block that started during the Middle Eocene (Illies, 1977). The rifting has formed the present Oberrhein (Upper Rhine) Graben that is part of the European Cenozoic Rift System (e.g.
Ziegler, 1994; Sissingh, 1998; Laubscher, 2001) (Fig. 2). Connected with the rifting is volcanic activity in the southern part of the graben, which is dated to ca. $61 \mathrm{Ma}$ on the western flank (Keller et al., 2002) and to 18 - $16 \mathrm{Ma}$ in the central Kaiserstuhl area (Lippolt et al., 1963). Midlands along the graben structure are the Schwarzwald (Black Forest), the Vosges, the Odenwald, the Pfälzerwald/Haard and the Saar-Nahe Depression built up by plutonic intrusions and late Palaeozoic to Mesozoic sediments, respectively. The rifting structure runs SSW to NNE and culminates in the Rhenish Triple Junction of the Mainz Basin (cf. Sissingh, 2003), an area that is partially covered by the remains of Tertiary marine transgressions. The older, now inactive branch of the rifting system continues via 
the Hessian Depression (Leine Graben) and is traced as far north as the Oslo Graben of southern Norway. The presently active part of the tectonic system runs from the Mainz Basin into a NW direction through the Rhenish Massif, the Lower Rhine Embayment (including the Roer Valley Rift System), the West and Central Netherlands Basins and continues with the Central Graben of the North Sea (Ziegler, 1994) (Fig. 2).

The Rhenish Massif is built up by rocks of mainly Devonian and Carboniferous age, which were folded during the Variscian orogeny of the Late Palaeozoic. The Mittelrhein (Middle Rhine) area as part of the Rhenish Massif represents a region generally affected by uplift with local areas of subsidence such as the Neuwied Basin. The uplift caused the formation of a flight of Rhine terraces, which documents both the tectonic and climatic history during the Quaternary (e.g. Kaiser, 1903; Bibus, 1980; Schirmer, 2003). Connected to the tectonic activity is volcanism of Tertiary and Quaternary age along the Rhine, such as in the Eifel and Siebengebirge volcanic fields (cf. van den Bogaard \& Schmincke, 1990; Schreiber \& Rotsch, 1998; Goes et al., 1999).

The Niederrheinische Bucht (Lower Rhine Embayment) is characterised by two periods of subsidence during the Late Paleocene and Oligocene-Quaternary time intervals (cf. Michon et al., 2003). The basin is subdivided by a series of tectonic blocks showing differential vertical movement with local highs and lows (e.g. Ahorner, 1962). Quaternary deposits reach a thickness of several tens of meters and cover mid to late Tertiary sediments including economically important Miocene brown coal deposits. The latter are mined in huge open cast pits that allow a spectacular view into the earth history.

The continuation of the rift system in the Netherlands (Roer Valley Rift System) is expressed by strong differences in thicknesses of Quaternary sediments ranging between $10 \mathrm{~m}$ (Peelhorst) and $250 \mathrm{~m}$ (Roer Valley Graben). The depth of the Quaternary base increases towards the northwest and is located below $600 \mathrm{~m}$ offshore (Zagwijn, 1989). The region is generally characterised by a very flat topography. During interglacials such as the Holocene, the River Rhine has developed a highly active delta at the margin of the North Sea. During glacial times of low global sea level large parts of the shelf were exposed and the course of the Rhine was extended by several hundreds of kilometres into the North Sea Basin and finally into the North Atlantic. This tectonically constrained southeast-northwest route was drastically changed during late Middle Pleistocene glaciations when the Fennoscandian ice sheet forced the Rhine system to follow a western course through the English Channel (La Manche) (Gibbard, 1988; Reynaud et al. 2003).

\section{The headwaters (Hochrhein and Vorderrhrein)}

Two separate medium-scaled rivers, the Vorderrhein and Hinterrhein, drain the headwaters of the Rhine in the central Swiss Alps (Fig. 1). Both systems have several minor tributaries some of which also bear the name 'Rhine' (e.g. Valser Rhein,
Rein d'Avers). The Vorderrhein originates from the Oberalppass area and follows major tectonic lines through the mainly plutonic and metamorphic basement of the Aare and Gotthard Massif. The source of the Hinterrhein lies in the crystalline Aduala nappe and flows to the north through the Via Mala gorge and basement mainly consisting of schists ('Bündner Schiefer'). During the last glaciation (ca. 20 ka ago), the headwaters of the River Rhine, together with the Alpenrhein, the Bodensee (Lake Constance), and the eastern part of the Hochrhein area, were covered by ice of the so-called Rhine glacier, one of the largest ices masses of the Alpine glaciation. The ice dome that developed in the Oberalppass area represented one of the main accumulation areas of Alpine ice during the last glaciation (Florineth, 1998; Florineth \& Schlüchter, 1998).

The rivers in the headwaters are characterised by coarse sediment load. Rock falls, avalanches and landslides repeatedly shifted the river's course. The most impressive of these mass movements is the Flims rockslide, which blocked the Vorderrhein close to its confluence with the Hinterrhein (Nabholz, 1975). This event is probably of Early Holocene age, as indicated by radiocarbon ages of 9500 cal. yr BP determined for pieces of wood found at the base of the rock fall deposits (von Poschinger and Haas, 1997; Schneider et al., 2004). The huge amount of rock fall material (ca. $15 \mathrm{~km}^{3}$ ) blocked the whole valley floor, dammed up the Vorderhein and caused the development of the so-called Lake Ilanz. Vertical erosion in the central part of the valley repeatedly caused outbursts of water and a subsequent lowering of the lake level, which is recorded by different lake terraces upstream of the rock fall levee. Erosion continued to cut into the rock fall material until it reached its natural level, which has led to the impressive gorge still present today.

\section{Alpenrhein (Alpine Rhine)}

From the confluence of Vorderrhein and Hinterrhein near the village of Reichenau onwards, the stream is called Alpenrhein (Alpine Rhine). It runs in a more or less straight south-north direction until it reaches the Bodensee (Lake Constance). The Alpenrhein mainly collects small tributaries, the two largest of which, the rivers Ill and Landquart, originate from the Silvretta Group located at the Swiss/Austrian border. Bedrock geology along the Alpenrhein Valley is characterised by nappes of intensively folded, mainly Mesozoic, sediments dominated by limestone. These nappes are partially thrusted over the North-Helvetic Flysch and over the Lower Marine and Lower Freshwater Molasse (Pfiffner, 1993). This indicates that thrusting was active at least until the Oligocene.

Characteristic young geological features along the southern part of the Alpenrhein are the mass movements of Tamins, Kunkel and Domat/Ems, which are presumably younger than the Flims event in the Hinterrhein area (Pfiffner et al., 1997; Schneider et al., 2004). Postglacial loess deposits in the central 
Alpenrhein Valley were first described by Escher von der Linth in the mid-19st century (cit. in Penck \& Brückner, 1901-09) but are not well exposed today and are only poorly investigated. Glacial landforms such as moraine ridges, kame terraces and meltwater channels, which belong to different stages of the melting of Würmian ice, characterise part of the Alpenrhein Valley (Keller \& Krayss, 1993, 2005; Krayss, 1996). The valley bottom itself is relatively flat, reaches a width of more than $5 \mathrm{~km}$ and has a quite different, more open character when compared to the valleys of the headwaters. The Würmian Rhine glacier difluenced near the present town of Sargans. While the smaller portion of the ice mass flowed through the Walensee passage, confluenced with the Linth glacier and terminated north of present Lake Zürich, the main branch followed the Alpenrhein Valley into the Bodensee area.

\section{Bodensee (Lake Constance)}

The Bodensee has a surface of $572 \mathrm{~km}^{2}$, a maximum depth of $254 \mathrm{~m}$, and a capacity of $48.5 \mathrm{~km}^{3}$ and is one of the largest lakes in Europe. It is subdivided into the small and shallow Untersee (Lower Lake) and the deeper Obersee (Upper Lake). The whole lake is situated within molasse sediment but its surroundings display a variety of geological features resulting from glacial erosion and deposition of meltwater deposits. The basin itself is a product of lowland glaciations, formed by repeated erosion of the ice of the Rhine glacier that may have already began during the late Early Pleistocene (Keller, 1994). The Bodensee basin was abandoned by the ice of the Rhine lobe after the last maximum Alpine glaciation, presumably approximately 17,500 yr ago (Keller \& Krayss, 2000). Since then the lake has slowly filled with sediment, thus recording changes in climate during the Late Glacial and Holocene (Wessels, 1998). During the melting down of the Würmian Rhine glacier, the Bodensee and a series of smaller connected lakes covered a large area of the Alpenrhein Valley (up to the present town of Chur). Subsequently, the basin of that former lake system within the Alps was filled up. The southernmost lake, Lake Chur, had already vanished about 16,000 yr ago but the last remains of a lake in the Rhine Valley existed into the early Holocene (Keller, 1994, 2003).

\section{Hochrhein}

At the present town of Konstanz, the Rhine leaves the Bodensee and is now called Hochrhein. It flows into a westerly direction and takes in the river Aare as its first major tributary river system. The river Aare has its headwaters in the Grimsel and Susten areas, within a mountain range partly above $4000 \mathrm{~m}$ elevation and thus one of the highest regions in the Alps. Near the town of Brugg, the Aare meets with two further mediumsized rivers, the Reuss and Limmat, which drain the central and eastern part of the western Swiss Alps. During most of its course, the Hochrhein cuts into Mesozoic limestone of the Table Jura. The famous Rhine Falls at the town of Schaffhausen are the product of a Late Pleistocene change of the river course.

The oldest deposits in this region that are attributed to a proto-River Rhine system are exposed at Irchel, an inselberg made up by molasse and topped by gravel deposits ('Höhere Deckenschotter'; Graf, 1993). The coarse gravel is divided into four subunits of glaciofluvial deposits originating from the Linth-Walensee branch of a former Rhine Glacier (Graf, 2000). Faunal remains found within overbank deposits intercalated with the gravel are dated to vertebrate unit MN17 (Bolliger et al., 1996), which corresponds to an age of 2.3 to $1.8 \mathrm{Ma}$ (Earliest Pleistocene). The next younger unit is a complex of gravel deposits ('Tiefere Deckenschotter') and overbank deposits, some of which display evidence of intense weathering (Graf, 2000). The three different gravel layers within this unit presumably represent three independent glaciations of unknown age and without any feasible correlation to the classical stratigraphic system of the Alps (cf. van Husen, 2000).

While the gravel deposits of the two 'Deckenschotter' units represent a drainage pattern quite different from today, the lower levels of the High and Low Terraces show a similar flow direction to the present River Rhine. However, this frequently used simple dichotomy, based on morphological observations, is apparently oversimplifying the complex sedimentation history. This is indicated by the internal composition of terrace and glacial deposits (Graf, 2000) as well as by the first geochronological results (Preusser \& Graf, 2002). According to recent investigations it is likely that the High and Low Terraces represent at least four glacial episodes (Graf \& Hofmann, 2000).

\section{Oberrhein (Upper Rhine) and Mainz Basin}

At the city of Basel, the River Rhine changes its direction and flows in a NNE direction following the tectonic structure of the Upper Rhine Graben, which is part of the European Cenozoic Rift System (Fig. 2). The Valley is $35-40 \mathrm{~km}$ wide and reaches from the northern slope of the Jura Mountains to the southern border of the Rhenish Massif. The major tributary rivers fed by the Rhine are the River Neckar, originating from the eastern midlands of the Schwäbische Alb, and the River Main, draining a substantial part of central Germany. The eastern flank of the graben (Schwarzwald (Black Forest), Odenwald, Kraichgau Depression) is built by exhumed pre-Permian granitic basement and Permian to Mesozoic sediments. The so-called 'Vorbergzone', mainly built of Jurassic limestone, is located at the western margin of the Schwarzwald. West of the graben, the Vosges Mountains are an equivalent of the Schwarzwald followed to the north by Mesozoic (Zabern Depression, Haard/Pfälzerwald) and Permian (Saar-Nahe Depression) deposits. Evidence for young tectonic uplift is found on both flanks of the graben, 
for example at the Forst site, where Middle Pleistocene loesspalaeosol deposits are vertically dislocated along strongly altered Triassic sandstones (Weidenfeller \& Zöller, 1996).

Deposition within the graben structure began in the midEocene. Cenozoic sediments reach a maximum thickness of $3300 \mathrm{~m}$ in the Heidelberg Basin (Doebl \& Olbrecht, 1974). Initial deposition of limestone and lignite, reflecting limnic environments, are followed by a mainly marine influence during the Upper Eocene to Miocene. Late Tertiary sediments are well preserved only in the northern part of the graben and reflect brackish to lacustrine conditions (cf. Sissingh, 1998). The earliest sedimentary evidence of a river system roughly following the drainage pattern of the present Rhine is preserved by the Late Miocene Dinotherium Sands, which bear a rich subtropical fauna. Originally described in the Mainz Basin, similar deposits are also found in the western part of the Upper Rhine Graben (Bartz, 1936; Boenigk, 1987).

Young Cenozoic sediments reach their maximum thickness in the Heidelberg Basin ( $>1000 \mathrm{~m}$ ). However, the position of the Pliocene/Pleistocene boundary within these deposits as well as the whole stratigraphy of the Upper Rhine Graben is rather controversial (cf. Ellwanger et al., 1995; Fetzer et al. 1995). Generally, the sediments of the Upper Rhine Graben show a trend towards smaller grain size from south to north. The oldest unit, Iffezheim Formation, is mainly built up by sandy sediments of an explicitly pronounced local origin. The next younger unit, Breisgau Formation, consists in the southern graben of diamictic gravel and a mixture of alpine and local (Schwarzwald) material. The youngest unit, the Young Gravel, represents coarse alpine meltwater deposits including prominent drift blocks in the southern graben. In the northern graben this unit consists of sand and gravel (Ellwanger et al., 2003).

At the northern margin of the Mainz basin, the 'Weisenauer Sande' are interpreted as representing Early Pleistocene deposits of the River Rhine system (Semmel, 1983). The Middle Pleistocene is represented by the sediment series of the 'Mosbacher Sande' (Brüning, 1970; Boenigk, 1978a; Bibus, 1980). Terrace deposits reflect fluvial activity during the Late Pleistocene, similar to the Middle Rhine Area (cf. Fetzer et al., 1995).

\section{Mittelrhein (Middle Rhine) Area}

Near the town of Bingen, the River Rhine leaves the Mainz Basin entering the western part of the Rhenish Massif and cutting deeply into the Palaeozoic basement. This section of the Mittelrhein represents an outstanding example of an antecedent valley in central Europe. The Rhine collects two major tributary systems during this part of the course, the rivers Lahn and Mosel. The Lahn originates from the Rothaargebirge in the eastern part of the Rhenish Massif. This river subdivides the massif into Westerwald (north of the Lahn river ) and Taunus (south of the Lahn river). One of the largest tributaries of the Rhine is represented by the river Mosel having its headwaters in the southern Vosges Mountains, France. Similar to the eastern part of the Rhenish Massif, the river marks the border between two regions, Eifel $(\mathrm{N})$ and Hunsrück (S). The Neuwied Basin, an area of local subsidence, divides the Mittelrhein Area into an upper and lower section (Fig. 1).

Along the Rhine Valley, the Rhenish Massif is mainly built up by intensively folded, partly thrusted, Lower Devonian shale and sandstone deposited in a shallow marine environment. Main deformation took place as part of the Variscian orogeny during the Upper Devonian and Lower Carboniferous (cf. Meyer, 1994). Since the late Palaeozoic, the Rhenish Massif was an elevated area affected by erosion and weathering (Felix-Henningsen, 1990). Since the Upper Oligocene, the region has been subject to increased uplift first coinciding with volcanism in the Westerwald (e.g. Siebengebirge) and later, starting approximately $700 \mathrm{ka}$ ago, in the East Eifel region (van den Bogaard \& Schmincke, 1990). Shallow lakes developed during this time as a result of differential uplift of the basement and filling-up of these depressions with finegrained sediment originating from displacement of in-situ weathered Devonian rocks (e.g. Bottke, 1963).

The oldest sedimentary evidence of a fluvial system in the Middle Rhine Area is represented by patchy remains of the socalled Vallendar river system found on the elevated plains along the Middle Rhine Valley (Mordziol, 1908; cf. Schnütgen, 2003). The headwaters of this river system were presumably in the Vosges Mountains but its exact course is inadequately understood. Deposition of this gravel is presumably of Late Eocene to Oligocene age (Schnütgen, 2003). A similar source area is attributed to the Late Miocene/Pliocene river system of the Kieseloolite Formation (cf. Quitzow, 1978; Bibus, 1980; Boenigk, 1981). The flight of Quaternary fluvial terraces is usually subdivided into three different major sections called Main, Middle, and Lower Terrace (Kaiser, 1903). Bibus (1980) introduced an alternative approach by numbering the terraces from oldest to youngest $\left(t_{R 1}=\right.$ Earliest Quaternary; $t_{R 12}=$ Latest Quaternary / Holocene). The Main Terrace covers most of the widespread plateau above the Rhine Valley and is usually subdivided into an older and a younger subunit. However, there is evidence indicating one further younger, as well as one older, subunit of the Main Terrace (Bibus, 1980; Boenigk \& Hoselmann, 2003). At least three subunits of the Middle Terrace are found in the valley but are usually poorly preserved (cf. Bibus, 1980; Schirmer, 2003). The Lower Terrace as the youngest unit also shows a clear differentiation into several subunits. Deposition of the younger Lower Terrace took place after the Laacher See eruption, dated to 12900 yr BP (Brauer et al., 1999; cf. Litt et al., 2003). This age of terrace aggradation is clearly indicated by the presence of reworked Laacher See Tephra within the gravel deposits. Assuming cold climatic conditions during formation, the older Lower Terraces is 
assigned to the last glaciation (cf. Schirmer, 1990a). Schirmer (1990b) described an older subunit of the Lower Terrace from the Neuwied Basin that presumably reflects an early phase of aggradation during the last glaciation (cf. Schirmer, 2003). While the lower Middle Terrace is usually interpreted to reflect the Penultimate glaciation, correlation of older terraces is only tentative. Correlations are based on the stratigraphy of cover sediments on top and on the content of volcanic minerals within the gravel deposits (Boenigk \& Frechen, 2006). Following this approach, the younger Main Terrace is older than the onset of volcanic activity in the Eifel, and so, older than 700 ka (Boenigk, 1995).

\section{Niederrhein (Lower Rhine)}

At the town of Bonn, the Rhine leaves the Rhenish Massif and enters the Niederrheinische Bucht (Lower Rhine Embayment) as part of the lowlands of northern central Europe. East of the river, the Rhenish Massif continues with the midlands of Bergisches Land. The SW margin of the embayment consists of Palaeozoic rocks of the Hohes Venn midlands. West of the present course of the River Rhine follows a series of differentially uplifted tectonic blocks with Tertiary sediments located near the present surface (e.g. Miocene brown coal). This area and the Roer Valley Rift System that continues to the north of it correspond to the northern segment of the European Cenozoic Rift System (cf. Michon et al., 2003). Major tributaries to the Rhine in the Lower Rhine Embayment are the rivers Sieg, Ruhr, and Lippe, all of which originate from the eastern midlands. The only important tributary to the west of the Rhine is the River Erft with its headwaters at the northern slope of the Rhenish Massif.

Tertiary to Quaternary sediments are well exposed in the Lower Rhine Embayment in huge open cast brown coal mines and several gravel pits. Miocene to Pliocene deposits consist of interbedded strata of sand/gravel with clay/lignite. This succession represents a marine deltaic setting with partially lagoonal and swampy environments (Boenigk, 1981). A pronounced change in heavy mineral composition of the Rhine deposits occurred during the latest Pliocene (Boenigk, 1978a). Fluvial deposits of the River Rhine, which are well exposed in several pits along the Dutch/German border have been interpreted to represent an exceptional record of Early Pleistocene stratigraphy (cf. Boenigk, 1978b; Zagwijn, 1985, 1992; Gibbard et al., 1995).

The stratigraphy of staged terraces in the southern part of the Lower Rhine Embayment generally follows that of the Middle Rhine with its allocation of Main, Middle and Low Terraces, but the subdivision of this is even more complex in parts (cf. Brunnacker et al., 1982; Boenigk, 1995; Klostermann, 1995; Schirmer, 2003; Boenigk \& Frechen, 2006). Both Main and Middle Terraces are subdivided into several sub-members but little is known about the absolute age of the different units (cf. Boenigk \& Frechen, 2006). Towards the North, the vertical distance between the separate terrace levels decreases steadily due to the reduced impact of uplift that affected the southern part of the basin. From around the Dutch/German border onwards to the North Sea (hinge line; cf. Törnqvist, 1995), the fluvial sediments are found as stacked bedding. Prominent geomorphic features in the northern Lower Rhine Embayment are Saalian ice-pushed ridges (terminal moraines) and the presence of the Scandinavian ice sheet had an important impact on the course of the River Rhine (see below).

\section{Rhine Delta}

The change from the Niederrhein to the delta roughly coincides with the political border between Germany and the Netherlands. In the Netherlands, the present Rhine discharge is divided among three major branches, the Nederrijn-Lek (2/9 of total annual discharge), the Waal (6/9 of total annual discharge) and the IJssel (1/9 of total annual discharge). The Nederrijn-Lek and Waal continue their courses to the west and form a spacious delta together with the River Meuse. The smaller River IJssel flows to the north entering the IJsselmeer (a lake that remained after damming of the former Zuiderzee in 1932).

From a tectonic point of view, the Rhine delta is situated at the southern margin of the North Sea Basin. The south eastern margin of this basin is built up by the Rhenish Massif. Rifting in the Roer Valley Rift system started during the Oligocene and continues to the present day (Michon et al., 2003). Tectonic movements related to the development of the rift system form one of the major controlling factors of the southern North Sea Basin leading to a succession of stacked sand and clay deposits (Cohen, 2003). The other controlling factors on the development of the Rhine delta are environmental (i.e. climate) conditions (Busschers et al., 2005), shifting positions of coastal lines due to global sea-level change (Törnqvist et al., 2000; Wallinga et al., 2004) and isostacy (Wallinga et al., 2004; Busschers et al., 2005).

While the present delta region was situated in a marine environment during the early and mid Tertiary, the fluvial influence started with the general lowering of sea level towards the Quaternary (de Mulder et al., 2003). Since the Late Pliocene, sedimentation in the Netherlands has been mainly fluvial but was repeatedly interrupted by marine ingressions (cf. Zagwijn, 1989; Berendsen, 1998, 2004). The Rhine and Meuse, together with small rivers draining the Scheldt catchment, controlled deposition in the southern basin. The northern and eastern part of the Netherlands was influenced by the so-called Eridanos system that drained most of the Fennoscandian and Baltic Shield as well as eastern Central Europe (Zagwijn, 1974; 0vereem et al., 2001). After termination of the Baltic river system in the late Early Pleistocene, deposition of primarily coarse grained Rhine sediments occurred in a structurally controlled southeast-northwest oriented zone. 
The Elsterian and Saalian glaciation had a large impact on the River Rhine system since the North Sea Basin was covered by ice and forced the Rhine into a SW direction (see below). At the end of the Eemian, sediments of the River Rhine had filled completely the IJssel glacial basin. The Rhine first flowed in a northerly direction but shifted to a more southerly course during the early part of the last glaciation (cf. Bosch et al., 2000; Wallinga et al., 2004; Busschers et al., 2005). The Holocene evolution of the Rhine-Meuse delta was governed by complex interactions of the location of the Late Weichselian palaeovalley, sea level rise, peat formation and neotectonics (Berendsen \& Stouthamer, 2000), leading to frequent avulsions (Berendsen and Stouthamer, 2001).

\section{Evolution of the River Rhine system}

The present River Rhine system experienced several important evolutionary developments during the Late Cenozoic (Fig. 3). The first evidence of fluvial activity along the present course of the Rhine is represented by the Late Eocene to Oligocene Vallendar river system (cf. Schnütgen, 2003). However, the assumed origin of this system in the Vosges Mountains suggests an interpretation as a proto-Mosel rather than an explicit predecessor of the Rhine. It is probable that another early drainage system existed in the Upper Rhine Graben that followed the direction of the present Rhine during at least part of the Oligocene (Schirmer, 2003). During the Miocene, the river systems in the Middle Rhine Area and the Upper Rhine Graben were connected and drained into the Lower Rhine Embayment (Boenigk, 1982). The proto-Rhine system later extended its catchment to the northern slope of the Jura Mountains during the Pliocene (Boenigk, 1987).

In the foreland of the rising Alps, a fluvial system (Lower Sweetwater Molasse) developed during the Late Oligocene / Early Miocene that drained to the East, into the Pannonian Basin (cf. Keller, 2000). This system was flooded during the marine ingression of the Early Miocene (Upper Marine Molasse) but small to medium-scaled rivers from the Alps continued to drain in the direction of the former river system. One of these rivers, Toggenburger Rhein according to Schirmer (2003), probably drained a similar area, taking into account the ongoing sculpting of the Alps, as do the present Vorder- and Hinterrhein. After the marine regression during the late Early Miocene, another large fluvial system (Upper Sweetwater Molasse - 'Glimmersandsteinrinne') developed in the northern foreland of the Alps that flowed into a south westerly direction. With further uplift of the Alps during the Miocene, the drainage pattern of this system was inverted causing the establishment of the so-called Aare-Donau river (Fig. 3) that comprised the headwaters of both the present Aare and Rhone rivers (Petit et al., 1996). During the middle Pliocene, the Aare was captured by the palaeo-Doubs river and flowed into the Bresse graben ('Sundgau gravel'; cf. Giamboni et al., 2004).
Several aspects in relation to the Pliocene / Early Pleistocene course of the Rhine in the Alpine Foreland are still controversial. The Alpenrhein was a tributary of the River Donau (Danube) at that time and drained in a northeasterly direction (e.g. Villinger, 1998). According to Villinger (1998), the headwaters of the Rhine (Vorder- and Hinterhein) were tributaries of the Danube system until the Early Pleistocene. In contrast, Graf (1993) presented evidence from the Hochrhein indicating that one branch of the Rhine, probably representing Vorderrhein and Hinterrhein, flowed through the Walensee passage in a NW direction. According to this reconstruction, this branch of the Rhine joined the River Aare and followed it in a westerly direction (Graf, 1993; cf. Ellwanger et al., 2003). Since the Early Pleistocene, the Aare system has been connected to the Oberrhein, indicated by the appearance of metamorphic heavy minerals in Rhine deposits (Zonneveld, 1958; Boenigk, 1982). The capture of the Alpenrhein by the Aare/Rhine system is probably related to landscape sculpting caused by Alpine glaciers during the Middle Pleistocene (Ellwanger et al., 2003). Since then, the Rhine in the Alpine Foreland follows approximately its present course, apart from a change in the upper part of the Hochrhein caused by ice geometry during the Last Glacial Maximum (cf. Graf, 2000).

While the course of the Rhine was rather similar to that of the present in the Upper Rhine Graben and Middle Rhine area, some changes have been recognised in the lower part of the River Rhine. During the Early Pleistocene, the course of the Rhine was situated further to the West (Fig. 3) and migrated subsequently to the East (Boenigk, 1978b). During the Elsterian, and in particular during the early part of the Saalian glaciation, when the Rhine occupied a similar course to today in the Lower Rhine Embayment, Scandinavian ice that reached that far south forced the Rhine into a more westerly course (Fig. 3).

In the Netherlands the Late Pliocene and Early Pleistocene Rhine deposited large amounts of sediments belonging to the Kieseloolite and Waalre Formations (De Mulder et al., 2003), while the Baltic Eridanos system formed a second much larger delta system to the north (Zagwijn, 1989). A strong net extension of this deltaic system occurred throughout the Early Pleistocene. During the Middle Pleistocene the Rhine started to deposit primarily coarse-grained sediments with intercalated clay layers belonging to the Sterksel Formation. Deposition of Rhine sediments primarily occurred within the Roer Valley Graben until this area was abandoned approximately $500 \mathrm{ka}$ ago (Schokker, 2003) and the Rhine started to incise a new river valley further to the east. Approximately $450 \mathrm{ka}$ ago the heavy mineral augite became abundant in the Rhine sediments, in deposits referred to as the Urk Formation. Although little is known about the pre-Elsterian Rhine courses further downstream, presumably the Rhine continued into the central North Sea (Gibbard, 1988, 1995).

A major re-arrangement of drainage in the North Sea area occurred during the Elsterian glaciation. The ice sheet of the 

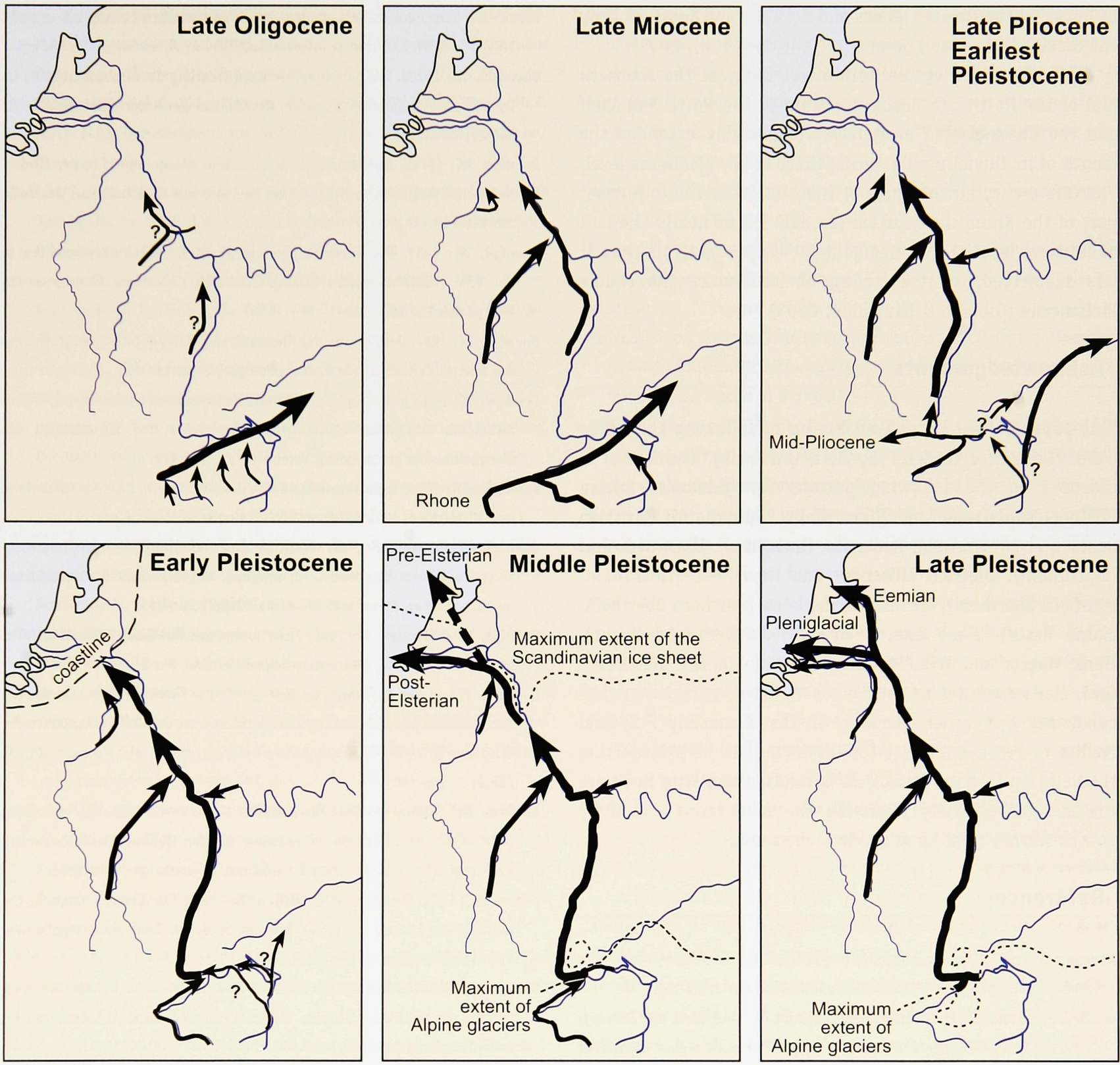

Fig. 3. Development of the Rhine drainage system since the Mid Oligocene (after Boenigk, 1978b, 1982; Ellwanger et al., 1995; Gibbard, 1988, 1995; Graf, 1993; Keller, 2000; Schirmer, 2003; Schlüchter, 2004; Schnütgen, 2003; Törnqvist et al., 2000, Van de Meene \& Zagwijn, 1978).

Elsterian glaciation forced the Rhine to the SW, through the Strait of Dover, instead of draining into the North Sea Basin (Gibbard, 1988). The same flow path was followed during the Saalian glaciation when an ice-marginal Rhine system was forced to flow through the western Netherlands (Thome, 1959; Van de Meene \& Zagwijn, 1978; Busschers et al., 2005). During the Saalian deglaciation, the Rhine avulsed and took a northerly course through the glacially eroded depression at the location of the present IJssel Valley, where it most probably stayed until the onset of the Weichselian Pleniglacial (Van de Meene \& Zagwjn, 1978; Törnqvist et al., 2000; Törnqvist et al., 2003; Wallinga et al., 2004). Later on, it re-shifted again towards the western Netherlands and deposited a $10-25 \mathrm{~m}$ thick stacked sequence of mid Weichselian gravel-bearing sand deposits capped by Holocene deposits (Van de Meene \& Zagwijn, 1978; Busschers et al., 2005).

The Elsterian glaciation caused the formation of a huge icedammed lake in the southern part of the North Sea that collected all major fluvial systems of the region including the Rhine (Ter Wee, 1983; Gibbard, 1988). Spillage from this lake caused substantial erosion in the English Channel (La Manche) area. During the Saalian, when the North Sea was again mainly covered by ice, this already existing line was used to drain most of central Europe and England (Gibbard, 1988, 1995). The Rhine system, together with afflux from the East (e.g. Weser river) and South (Meuse), was joined north of the Strait 
of Dover by the Rivers Thames and Scheldt, and south of it by the Somme, Seine, and Solent (cf. Antoine et al., 2003).

While the Rhine system terminates today at the southern end of the North Sea Basin, exposure of the North Sea shelf and the Channel area must have considerably extended the length of its fluvial profile during times of low global sea level. The Quaternary climate history indicates that the lowermost part of the Rhine river system (ca. $800 \mathrm{~km}$ or nearly the half of its total length) was emergent for longer intervals than it was submerged, as it is today, at least since the Middle Pleistocene (Gibbard \& Lautridou, 2003).

\section{Acknowledgements}

This paper benefited from an excursion following the Rhine 'From the source to delta' by Bern University. The author is indebted to the following persons for guidance: Adrian Pfiffner (Vorderrhein and Hinterrhein, Alpenrhein), Christian Schlüchter (Alpenrhein, Bodensee, Hochrhein), Hansruedi Graf (Hochrhein), Dietrich Ellwanger and Inge Neeb (Hochrhein, southern Oberrhein), Michael Weidenfeller (northern Oberrhein, Mainz Basin), Hans Axel Kemna (Niederrheinische Bucht), Henk Weerts and Wim Westerhoff (Rhine Delta). Hansruedi Graf, Hans Axel Kemna and Jakob Wallinga provided critical comments on earlier versions of the manuscript. Special credits to Freek Busschers for his incredible help in getting the delta up-to-date. Henk J.A. Berendsen and Wim Hoek are thanked for critically reviewing the manuscript and Sally Lowick for her final language improvements.

\section{References}

Ahorner, L., 1962. Untersuchungen zur quartären Bruchschollentektonik der Niederrheinischen Bucht. Eiszeitalter und Gegenwart 13: 24-105.

Antoine, P., Coutard, J.P., Gibbard, P., Hallegouet, B., Lautridou, J.P. \& Ozouf, J.P., 2003. The Pleistocene rivers of the English Channel region. Journal of Quaternary Science 18: 227-243.

Aguirre, E. \& Passini, G., 1995. The Pliocene-Pleistocene boundary. Episodes 8: 116-120.

Bartz, J., 1936. Das Unterpliozän in Rheinhessen. Jahresberichte und Mitteilungen des oberrheinischen geologischen Vereins NF 25: 121-228.

Berendsen, H.J.A., 1998. Birds-eye view of the Rhine-Meuse delta (the Netherlands). Journal of Coastal Research 14: 740-752

Berendsen, H.J.A., 2004. Rivers and the sea: how science went wrong explaining the formation of the Netherlands' coastal plain. In: Dietz, T., Hoekstra, P., \& Thissen, F. (eds): The Netherlands and the North Sea. Dutch Geography 2000 - 2004. Netherlands Geographical Studies 325: 56-63.

Berendsen, H.J.A. \& Stouthamer, E., 2000. Late Weichselian and Holocene palaeogeography of the Rhine-Meuse delta, the Netherlands. Palaeogeography, Palaeoclimatology, Palaeoecology 161: 311-335.

Berendsen, H.J.A. \& Stouthamer, E., 2001. Palaeogeographic development of the Rhine-Meuse delta, the Netherlands. Assen: Koninklijke Van Gorcum: $268 \mathrm{pp}$.
Bibus, E., 1980. Zur Relief-, Boden- und Sedimententwicklung am unteren Mittelrhein. Frankfurter Geowissenschaftliche Arbeiten Serie D 1: 296 pp.

Boenigk., W., 1978a. Zur petrographischen Gliederung der Mosbacher Sande im Dyckerhoff-Steinbruch, Wiesbaden/Hessen. Mainzer Naturwissenschaftliches Archiv 16: 91-126.

Boenigk, W., 1978b. Gliederung der altquartären Ablagerungen in der Niederheinischen Bucht. Fortschritte in der Geologie von Rheinland und Westfalen 28: 135-212.

Boenigk, W., 1981. Die Gliederung der tertiären Braunkohlendecksichten in der Ville (Niederrheinische Bucht). Fortschritte Geologie Rheinland und Westphalen 29: 193-263.

Boenigk, W., 1982. Der Einfluss des Rheingrabensystems auf die Flussgeschichte des Rheins. Zeitschrift für Geomorphologie NF 42: 167-175.

Boenigk, W., 1987. Petrographische Untersuchungen jungtertiärer und quartärer Sedimente am linken Oberrhein. Jahresberichte und Mitteilungen des oberrheinischen geologischen Vereins NF 82: 113-129.

Boenigk., W., 1995. Terrassenstratigraphie des Mittelpleistozäns am Niederhein und Mittelrhein. Mededelingen Rijks Geologische Dienst 52: 71-81.

Boenigk, W. \& Hoselmann, Ch., 2003. Tertiäre und unterpleistozäne Terrassenablagerungen am Mittelrhein. In: Schirmer, W. (ed.): Landschaftsgeschichte im europäischen Rheinland, GeoArcheoRhein 4: 81-124.

Boenigk, W. \& Frechen, M., 2005. The Pliocene and Quaternary fluvial archives of the Rhine system. Quaternary Science Reviews 25: 550-574.

Bogaard, P. van den \& Schmincke, H.U., 1990. Die Entwicklungsgeschichte des Mitelrheinraumes und die Eruptionsgeschichte des 0steifel-Vulkanfeldes. In: Schirmer, W. (ed.): Rheingeschichte zwischen Mosel und Meuse, DEUQUAFührer 1: 166-190.

Bolliger, Th, Feijfar, O., Graf, H. \& Kölin, D.W., 1996. Vorläufige Mitteilung über Funde von pliozänen Kleinsäugern ais den Höheren Deckenschottern des Irchels (Kt. Zürich). Eclogae geologicae Helvetiae 89: 1043-1048.

Bosch, J.H.A., Cleveringa, P. \& Meijer, T., 2000. The Eemian stage in the Netherlands: history, character and new research. Geologie \& Mijnbouw / Netherlands Journal of Geosciences 79: 135-145

Bottke, H., 1963. Die Tonlagerstätten der Höhrer Löcher bei Vallendar/Rhein am 0strand des Neuwieder Beckens. Notizblatt des hessischen Landesamtes für Bodenforschung 91: 256-276.

Brauer, A., Endres, Ch. \& Negendank, J.F.W., 1999. Late glacial calendar year chronology based on annually laminated sediments from Meerfelder Maar, Germany. Quaternary International 61: 17-25.

Brüning, H., 1970. Zur Klima-Stratigraphie der pleistozänen Mosbacher Sande bei Wiesbaden (Hessen). Mainzer Naturwisenschaftliches Archiv 9: 204-256.

Brunnacker, K., Löscher, M., Tillmanns, W. \& Urban, B., 1982. Correlation of the Quaternary terrace sequence in the Lower Rhine Valley and Northern Alpine Foothills of Central Europe. Quaternary Research 18: 152-173.

Busschers, F.S, Weerts, H.J.T., Wallinga, J., Cleveringa, P., Kasse, C. \& de Wolf, $H ., 2005$. Sedimentary architecture and optical dating of Middle and Late Pleistocene Rhine-Meuse deposits - fluvial response to climate change, sea-level fluctuation and glaciation. Netherlands Journal of Geosciences 84: 25-41.

Clague, J., 2006. Open letter to INQUA Executive Committee. Quaternary International 154/155: 158-159. 
Cohen, K., 2003. Differential subsidence withn a coastal prism. Late-Glacial Holocene tectonics in the Rhine-Meuse delta, the Netherlands. Netherlands Geographical Studies 316: 208 pp.

De Mulder, F.J., Geluk, M.C., Ritsema, I.L., Westerhoff, W.E. \& Wong, Th.E. (eds), 2003. De ondergrond van Nederland. Wolters-Noordhoff (Groningen/ Houten): $370 \mathrm{pp}$.

Doebl, F. \& Olbrecht, W., 1974. An isobath map of the Tertiary base in the Rhinegrabe. In: Illies, J.H. \& Fuchs, K. (eds): Approaches to Taphrogenisis. Schweizerbart (Stuttgart): 71-72.

Ellwanger, D., Bibus, E., Bludau, W., Kösel, M. \& Merkt, J., 1995. BadenWürttemberg. In: Benda, L. (ed.): Das Quartär Deutschlands, Stuttgart (Bornträger): 255-295.

Ellwanger, D., Lämmermann-Bartherl, J. \& Neeb, I., 2003. Eine landsschaftsübergreifende Lockergesteinsgliederung vom Alpenrand zum Oberrhein. In: Schirmer, W. (ed.): Landschaftsgeschichte im europäischen Rheinland, GeoArcheoRhein 4: 81-124.

Felix-Henningsen, P., 1990. Die mesozoisch-teriäre Verwitterungsdecke im Rheinischen Schiefergebirge. Relief Boden Paläoklima 6: 167 pp.

Fetzer, K.D., Larres, K., Sabel, K.-J., Spies, E.-D. \& Weidenfeller, M., 1995. Hessen, Rheinland-Pfalz, Sarrland. In: Benda, L. (ed.): Das Quartär Deutschlands, Stuttgart (Bornträger): 220-254.

Florineth, D., 1998. Surface geometry of the Last Glacial Maximum (LGM) in the southeastern Swiss Alps (Graubünden) and its paleoclimatological significance. Eiszeitalter und Gegenwart 48: 23-37.

Florineth, D. \& Schlüchter, Ch., 1998. Reconstructing the Last Glacial Maximum (LGM) ice surface geometry and flowlines in the Central Swiss Alps. Eclogae geologicae Helvetiae 91: 391-407.

Giamboni, M., Ustaszewski, K., Schmid, S.M., Schuhmacher, M.E. \& Wetzel, A., 2004. Plio-Pleistocene transpressional reactivation of Paleozoic and Paleogene structures in the Rhine-Bresse transformal zone (northern Switzerland and eastern France). International Journal of Earth Sciences (Geologische Rundschau) 93: 207-223.

Gibbard, P.L., 1988. The history of the great northwest European rivers during the past three million years. Philosophical Transactions of the Royal Society of London Series B 318: 559-602.

Gibbard, P.L., 1995. The formation of the Strait of Dover. In: Preece, R.C. (ed.): Island Britain: a Quaternary perspective. Geological Society Special Publication 96: 15-26.

Gibbard, P.L., 2004. Quatenary ... now you see it, now you don't. Quaternary International 129, 89-91.

Gibbard, P.L., Krook, L. \& Vandenberghe, J., 1995. Early Pleistocene depositional environments and stratigraphy at Öbel (Brüggen), NordrheinWestfalen, Germany. Mededelingen Rijks Geologische Dienst 52: 83-96.

Gibbard, P.L. \& Lautridou, J.P., 2003. The Quaternary history of the English Channel: an introduction. Journal of Quaternary Science 18: 195-199.

Gibbard, P.L., Smith, A.G., Zalasiewicz, J.A., Barry, T.L., Cantrill, D., Coe, A.L., Cope, J.C.W., Gale, A.S., Gregory, F.J., Powell, J.H., Rawson, P.F., Stone, P., Waters, C.N., 2005. What status for the Quaternary? Boreas 34: 1-6.

Goes, S., Spakman, W. \& Bijwaard, H., 1999. A lower mantle source for central European volcanism. Science 286: 1928-1931.

Graf, H., 1993. Die Deckenschotter der zentralen Nordschweiz. Diss ETH Zürich No. 10205: $151 \mathrm{pp}$.
Graf, H., 2000. Quartärgeologie zwischen Rhein, Thus und Aare (Kantone Aargau, Zürich und Schaffhausen) (Exkursion G am 28. Aprill 2000). Jahresberichte und Mitteilungen des oberrheinischen geologischen Vereins NF 82: 113-129.

Graf, H. \& Hofmann, F., 2000. Zur Eiszeitgeologie des oberen Klettgau (Kanton Schaffhausen, Schweiz). Jahresberichte und Mitteilungen des oberrheinischen geologischen Vereins NF 82: 279-315.

Illies, H., 1977. Ancient and recent rifting in the Rhine graben. Geologie en Mijnbouw 56: 329-350.

Kaiser, E., 1903. Die Ausbildung des Rheintales zwischen Neuwieder Becken und Bonn-Cölner-Bucht. Verhandlungen 14. deutscher Geographentag Köln: 206215.

Keller, B., 2000. Fazies der Molasse anhand eines Querschnittes durch das zentrale Schweizer Mitteland. Jahresberichte und Mitteilungen des oberrheinischen geologischen Vereins NF 82: 55-92.

Keller, J., Kraml, M. \& Henjes-Kunst, F., 2002. 40Ar/39Ar single crystal laser dating of early volcanism in the Upper Rhine Graben and Tectonic implications. Schweizerische Mineralogische und Petrographische Mitteilungen 82: 1-10.

Keller, O., 1994. Enstehung und Entwicklung des Bodensees - ein geologischer Lebenslauf. In: Holenstein, J., Keller, O., Maurer, H., Widmer, R. \& Züllig, H. (eds): Umweltwandel am Bodensee: 33-92.

Keller, 0., 2003. Die geologische Geschichte des Bodensees. Festschrift Bodensee (75 Jahre Yacht-Club Romanshorn). Ecomment AG (St. Gallen): 58-80.

Keller, 0. \& Krayss, E., 1993. The Rhine-Linth glacier in the Upper Wurm: A model of the last alpine glaciation. Quaternary International 18: 15-27.

Keller, 0. \& Krayss, E., 2000. Die Hydrogeographie des Bodenseeraums in Vergangenheit und Gegenwart. Berichte der St. Gallischen Naturwissenschaftlichen Gesellschaft 89: 39-56.

Keller, 0. \& Krayss, E., 2005. Der Rhein-Linth Gletscher im letzten Hochglzial 2 Teil: Datierung und Modelle der Rhein-Linth-Vergletscherung, Klimarekonstruktionen. Vierteljahresschrift der Naturforschenden Gesellschaft in Zürich 150: 69-85.

Klostermann, J., 1995. Nordrhein-Westfalen. In: Benda, L. (ed.): Das Quartär Deutschlands, Stuttgart (Bornträger): 59-94.

Krayss, E., 1996. Late glacial back-melting marks of the alpine icestream network (Rhine-Glacier, Wurm). Eclogae geologicae Helvetiae 89: 1105-1113.

Laubscher, H., 2001. Plate interactions at the southern end of the Rhine graben. Tectonophysics 343: 1-19.

Lippolt, H.J., Gentner, W. \& Wimmenauer, W., 1963. Altersbestimmungen nach der Kalium-Argon-Methode an tertiären Eruptivgesteinen Sudwestdeutschlands. Jahrbuch des geologischen Landesamtes Baden-Württemberg 6: 507-538.

Litt, Th., Schmincke, H.U. \& Kromer, B., 2003. Enviornmental response to climate and volcanic events in central Europe during the Weichelian Lateglacial. Quaternary Science Reviews 22: 7-32.

Meyer, W., 1994. Geologie der Eifel. Schweizerbart (Stuttgart): 618 pp.

Michon, L., Van Balen, R.T., Merle, O. \& Pagnier, H., 2003. The Cenozoic evolution of the Roer Valley Rift System integrated at a European scale. Tectonophysics 367: 101-126.

Mordziol, C., 1908. Über das jüngere Tertiär und das Dilluvium des rechtsrheinischen Teiles des Neuwieder Beckens. Jahrbuch der preußischen geologischen Landesanstalt 29: 348-430. 
Nabholz, W.K., 1975. Geologischer Überblick über die Schiefersackung des mittleren Lugnez und über das Bergsturzgebiet Ilanz-Flims-ReichenauDomleschg. Bulletin des Vereins Schweizer Petroleum-Geologen und -Ingenieure 42: 38-54.

Overeem, I., Weltje, G.J., Bishop-Kay, C. \& Kroonenberg, S.B., 2001. The Late Cenozoic Eridanos delta system in the Southern North Sea Basin: a climate signal in sediment supply? Basin Research 13: 293-312.

Partidge, T.C., 1997. Reassessment of the position of the Plio-Pleistocene boundary: Is there a case for lowering it to the Gauss-Matuyama palaeomagnetic reversal? Quaternary International 40: 5-10.

Penck A. \& Brückner E., 1901-1909. Die Alpen im Eiszeitalter. Tauchnitz (Leipzig): 1157 pp.

Petit C., Campy M., Chaline J. \& Bonvalot J., 1996. Major palaeohydrographic changes in Alpine foreland during the Pliocene-Pleistocene Boreas 25: 131143.

Pfiffner, O.A., 1993. The structure of the Helvetic nappes and its relation to the mechanical stratigraphy. Jounral of Structural Geology 15: 511-521.

Pfiffner, O.A., Heitzmann, P., Lehner, P., Frei, W., Pugin, P. \& Felber, M., 1997. Incision and backfilling of Alpine valleys: Pliocene, Pleistocene and Holocene processes. In: NFP20-Atlas: Deep structure of the Swiss Alps.

Poschinger, A. von \& Haas, U., 1997. Der Flimser Bergsturz, doch ein warmzeitliches Ereignis? Bulletin angewandte Geologie 2: 35-46.

Preusser, F. \& Graf H.R., 2002. Erste Ergebnisse von Lumineszenzdatierungen eiszeitlicher Ablagerungen der Nordschweiz. Jahrbuch und Mitteilungen des Oberrheinischen Geologischen Vereins 107: 419-438.

Quitzow, H., 1978. Der Abfall der Eifel zur Niederrheinischen Bucht im Gebiet der unteren Ahr. Fortschritte Geologie Rheinland und Westphalen 28: 9-50.

Remané, J., Faure-Muret, A. \& Odin, G.S., 2002. International Stratigraphic Chart. International Commission on Stratigraphy, UNESCO/IUGS.

Reynaud, J.Y., Tessier, B., Auffret., J.-P., Berné, S., Batist, M. de, Marsset, T. \& Walker, P., 2003. The offshore Quaternary sediment bodies of the English Channel and its western approaches. Journal of Quaternary Science 18: 361371.

Rijsdijk, K.F., Passchier, S., Weerts, H.J.T., Laban, C., van Leeuwen, R.J.W \& Ebbing, J.H.J., 2005. Revised Upper Cenozoic stratigraphy of the Dutch sector of the North Sea Basin: towards an integrated lithostraigraphic, seismostratigraphic and allostratigraphic approach. Netherlands Journal of Geosciences 84: 129-146.

Schirmer, W., 1990a. Die Goldene Meile. In: Schirmer, W. (ed.): Rheingeschichte zwischen Mosel und Meuse, DEUQUA-Führer 1: 94-98.

Schirmer, W., 1990b. Terrassentreppe am 0strand von Neuwied. In: Schirmer, W. (ed.): Rheingeschichte zwischen Mosel und Meuse, DEUQUA-Führer 1: 99-104.

Schirmer, W., 2003. Stadien der Rheingeschichte. In: Schirmer, W. (ed.): Landschaftsgeschichte im europäischen Rheinland (GeoArcheoRhein 4): 21-80.

Schlüchter, Ch., 2004. The Swiss glacial record - a schematic summary. In: Ehler, J., \& Gibbard, P.L. (eds): Quaternary Glaciations - Extent and Chronology (Developments in Quaternary Science 2): 413-418.

Schneider, J.-L., Pollet, N., Chapron, E., Wessels, M. \& Wassmer, P., 2004. Signature of Rhine Valley sturzstrom dam failures in Holocene sediments of Lake Constance, Germany. Sedimentary Geology 169: 75-91.
Schnütgen, A., 2003. Die Petrographie und Verbreitung tertiärer Schotter der Vallendar-Fazies im Rheinischen Schiefergebirge, ihre paläoklimatologische und -geographische Bedeutung. In: Schirmer, W. (ed.): Landschaftsgeschichte im europäischen Rheinland, GeoArcheoRhein 4: 155-191.

Schokker, J., 2003. Patterns and processes in a Pleistocene fluvio-aeolian environment. Nederlandse Geografische Studies 314: 141. pp.

Schreiber, U. \& Rotsch, S., 1998. Cenozoic block rotation according to a conjugate shear system in central Europe - indications from palaeomagnetic measurements. Tectonophysics 299: 111-142.

Semmel, A., 1983. Die plio-pleistozänen Deckschichten im Steinbruch MainzWeisenau. Geologisches Jahrbuch Hessen 111: 219-233.

Sissingh, W., 1997.Tectonostratigraphy of the North Alpine Foreland Basin correlation of Tertiary depositional cycles and orogenic phases. Tectonophysics 282: 223-256.

Sissingh, W., 1998.Comparative Tertiary stratigraphy of the Rhine Graben, Bresse Graben and Molasse Basin: correlation of Alpine foreland events. Tectonophysics 300: 249-284.

Sissingh, W., 2001. Tectonostratigraphy of the Western Alpine Foreland: correlation of Tertiary sedimentary sequences, changes in eustatic sea-level and stress regimes. Tectonophysics 333: 361-400.

Sissingh, W., 2003. Teriary paleogeographic and tectonostratigraphic evolution of the Rhenish Triple Junction. Palaeogeography, Palaeoclimatology, Palaeoecology 196: 229-263.

Ter Wee, M.W., 1983. The Elsterian Glacition in the Nethelands. In: Ehlers, J. (Ed): Glacial deposits in north-west Euope: 413-415.

Thome, K.N., 1959. Das Inlandeis am Niederrhein. Fortschritte in der Geologie von Rheinland und Westfalen 4: 197-246.

Törnqvist, T.E., 1995. Alluvial architecture of the Quaternary Rhine-Meuse system in the Netherlands - discussion. Geologie \& Mijnbouw 74: 183-186.

Törnqvist, T.E., Wallinga, J., Murray, A.S., Wolf, H. de, Cleveringa, P. \& De Gans, W., 2000. Response of the Rhine-Meuse system (west-central Netherlands) to the last Quaternary glacio-eustatic cycles: a first assessment. Global and Planetary Change 27: 89-111.

Törnqvist, T.E., Wallinga, J. \& Busschers, F.S., 2003. Timing of the last sequence boundary in a fluvial setting near the highstand shoreline Insights from optical dating. Geology 31: 279-282.

Villinger, E., 1998. Zur Flußgeschichte von Rhein und Donau in Südwestdeutschland. Jahrbuch und Mitteilungen des Oberrheinischen Geologischen Vereins NF 80: 361-398.

Van Husen, D., 2000. Geological processes during the Quaternary. Mitteilungen der Österreichischen Geologischen Gesellschaft 92: 135-156.

Van de Meene, E.A. \& Zagwijn, W.H., 1978. Die Rheinläufe im deutschniederländischen Grenzgebiet seit der Saale-Kaltzeit. Überblick neuer geologischer und pollenanalytischer Untersuchungen. Fortschritte in der Geologie von Rheinland und Westfalen 28: 345-359.

Wallinga, J., Törnqvist, T.E., Busschers, F.S. \& Weerts, H.J.T., 2004. Allogenic forcing of the late Quaternary Rhine Meuse fluvial record: the interplay of sea-level change, climate change and crustal movements. Basin Research 16: 535-547.

Weidenfeller, M. \& Zöller, L., 1996. Paläoböden und Neotektonik im Profil Forst am Westrand des Oberrheingrabens. Frankfurter Geowissenschaftliche Arbeiten D20: 89-100. 
Wessles, M., 1998. Natural environmental change indicated by Late Glacial and Holocene sediments from Lake Constance, Germany, Paleogeography, Paleoclimatology, Paleoecology 140: 421-432.

Zagwijn, W.H., 1974. The palaeogeographic evolution of the Netherlands during the Quaternary. Geologie en Mijnbow 5: 369-385.

Zagwijn, W.H., 1985. An outline of the Quaternary stratigraphy of the Netherlands. Geologie en Mijnbouw 64: 17-24.

Zagwijn, W.H., 1989. The Netherlands during the Tertiary and the Quaternary: a case history of coastal lowland evolution. Geologie en Mijnbouw 68: 107-120.

Zagwijn, W.H., 1992. The beginning of the ice age in Europe and its major subdivisions. Quaternary Science Reviews 11: 583-591.

Ziegler, P.A., 1994. Cenozoic rift system of western and central Europe: an overview. Geologie en Mijnbouw 73: 99-127.

Zonneveld, J.I.S., 1958. Lithostratigrafische eenheden in het Nederlandse Pleistoceen. Mededelingen von de Geologische Sichting Nieuwe Serie 12: 31-64. 